\title{
Homelessness across Alaska, the Canadian North and Greenland: A Review of the Literature on a Developing Social Phenomenon in the Circumpolar North
}

\author{
Julia Christensen, ${ }^{1}$ Steven Arnfjord, ${ }^{2}$ Sally Carraher ${ }^{3}$ and Travis Hedwig ${ }^{4}$
}

(Received 4 October 2016; accepted in revised form 26 June 2017)

\begin{abstract}
Over the past three decades, homelessness has become an area of significant social concern in Alaska, the Canadian North, and most recently, Greenland. These three geographical contexts show both similarities and contrasts, but no effort has yet been made to review the research literature on homelessness from these three regions or to highlight key themes or gaps in current knowledge. We reviewed the literature in order to 1) understand the current state of knowledge of the dynamics of homelessness in Alaska, the Canadian North (here including Yukon, Northwest Territories, and Nunavut), and Greenland and 2) conceptualize a northern geography of homelessness. The research literature identifies common themes across these contexts, which include chronic housing insecurity, overrepresentation of Indigenous peoples among those living homeless, and the significance of gendered experiences of homelessness. It identifies key interconnections between hidden homelessness and visible homelessness as the dynamics of urbanization in northern towns and cities reveal the social consequences of chronic housing insecurity in settlements. Across these northern regions, the high rates of chronic homelessness reflect the prevalence of northern housing insecurity and the lack of both adequate, appropriate support for people experiencing mental health or addiction problems and supportive or public housing options. Strategies that aim to diversify housing stock at various critical points along the housing spectrum are needed in northern regions, an idea that is promoted by Housing First and transitional housing programs in Alaska and the Canadian North.
\end{abstract}

Key words: homelessness; housing; urbanization; health; Alaska; Yukon; Nunavut; Northwest Territories; Greenland

RÉSUMÉ. Au cours des trois dernières décennies, le sans-abrisme est devenu une grande préoccupation sociale en Alaska, dans le Nord canadien et, plus récemment, au Groenland. Ces trois contextes géographiques présentent des similitudes et des différences, mais aucun effort n’a encore été déployé pour examiner la documentation de recherche sur le sans-abrisme dans ces trois régions ou pour mettre en évidence les principaux thèmes ou les principales lacunes en ce qui a trait aux connaissances actuelles. Nous avons dépouillé la documentation dans le but de 1) comprendre l'état actuel des connaissances sur les dynamiques du sans-abrisme en Alaska, dans le Nord Canadien (dans ce cas-ci le Yukon, les Territoires du Nord-Ouest et le Nunavut) et au Groenland, et 2) de conceptualiser une géographie nordique du sans-abrisme. La documentation de recherche fait ressortir des thèmes communs parmi ces contextes, notamment l'insécurité chronique en matière de logement, la surreprésentation des peuples autochtones parmi les itinérants et la signification de l'expérience du sans-abrisme selon le sexe. La documentation cerne les principaux liens entre le sans-abrisme caché et le sans-abrisme visible alors que les dynamiques de l'urbanisation dans les villages et les villes du Nord exposent les conséquences sociales de l'insécurité chronique en matière de logement dans les agglomérations. Dans l'ensemble de ces régions nordiques, les taux élevés de sans-abrisme chronique reflètent la prévalence de l'insécurité en matière de logement dans le Nord, le manque de soutien adéquat et approprié pour les gens aux prises avec des troubles de santé mentale ou de toxicomanie et le manque d'options de logements sociaux ou supervisés. Des stratégies visant à diversifier le parc de logements à divers points critiques de la gamme des logements s'avèrent essentielles dans les régions du Nord. D'ailleurs, l'approche Logement d'abord et les programmes de logement de transition font la promotion de cette idée en Alaska et dans le Nord canadien.

Mots clés : sans-abrisme; logement; urbanisation; santé; Alaska; Yukon; Nunavut; Territoires du Nord-Ouest; Groenland

Traduit pour la revue Arctic par Nicole Giguère.

\footnotetext{
${ }^{1}$ Department of Geography, Memorial University, St. John's, Newfoundland and Labrador A1B 3X9, Canada; julia.christensen@gmail.com

${ }^{2}$ Department of Social Work, University of Greenland, 1 Manutooq, 3905 Nuuk, Greenland; star@uni.gl

${ }^{3}$ Department of Anthropology, University of Alaska Anchorage, 3211 Providence Drive, Anchorage, Alaska 99508, USA; sfcarraher@alaska.edu

${ }^{4}$ Department of Health Sciences, University of Alaska Anchorage, 3211 Providence Drive, Anchorage, Alaska 99508, USA; thhedwig@alaska.edu
} 


\section{INTRODUCTION}

Over the past three decades, homelessness has emerged as an area of significant social concern in Alaska, the Canadian North, and most recently, Greenland, three geographical contexts that share many similarities, but provide interesting contrasts. No effort has yet been made to review the research literature from these three regions or to highlight key themes or gaps in current knowledge about the development of homelessness in northern regions. With interest increasing in both the dynamics of rural-to-urban migration and urbanization in the Arctic (see Howe, 2009; Dybbroe et al., 2010; Tròndheim, 2010; Fossland, 2012; Grydehøj, 2014; Nyseth and Pedersen, 2014), it is critical that scholars and policymakers begin to understand the diverse processes and forms of social marginalization in northern communities. Alongside the increasing concentration of social and economic resources in Arctic urban centers, a picture of increasing disparity and marginalization has appeared in certain sectors of these northern populations. The specific social, health, economic, political, and infrastructural challenges encountered in northern areas compound the dynamics and consequences of such disparity and marginalization. Underlying these challenges is the landscape of chronic housing insecurity across Alaska, the Canadian North, and Greenland since the introduction of modern housing programs. One result is high rates of hidden homelessness (i.e., temporarily staying with friends, relatives, or others because there is nowhere else to live and no immediate prospect of permanent housing), particularly in rural, remote, or settlement communities. Meanwhile, private housing markets in urban Arctic centers are often competitive and unaffordable, while the available public and subsidized housing does not meet demand (Falvo, 2011a; Christensen, 2012).

This review aims to outline the current state of the knowledge of the dynamics of homelessness in Alaska, the Canadian North (here including Yukon, Northwest Territories, and Nunavut), and Greenland and to conceptualize a northern geography of homelessness. These three particular geographical contexts were identified because homelessness has emerged as an issue of social concern in northern regions in recent decades. Scholars, policymakers, and community-based organizations, as well as northern media, are currently focusing on northern homelessness and housing need. We compare the scope and depth of the literature developed within these three geographical contexts, identify and elaborate upon the key themes that have emerged from the findings, highlight critical gaps in the literature, and suggest several important areas for further investigation.

\section{METHODS}

A scoping review is a broad-based inquiry that accommodates grey literature (e.g., reports from governments and NGOs), produces contextual accounts of the current state of knowledge, and supports the development of policy recommendations (Levac et al., 2010). Our review was guided by the five-part framework of Arksey and O'Malley (2005). First, we developed two interlinked scoping questions: (1) What is the current state of the knowledge of the dynamics of homelessness in Alaska, the Canadian North, and Greenland? and (2) What policy and service innovations and gaps have been documented in these three geographical contexts? These questions enabled us to examine both descriptive and analytical accounts of northern homelessness, highlight context-appropriate policy and service opportunities, and earmark areas where further research is needed.

The second step was to identify the relevant literature. We began by searching for academic and grey literature on homelessness research conducted in Alaska, the Canadian North, and Greenland between January 1990 and May 2016. We identified relevant grey literature using the Internet, as well as our own professional networks, to locate the various reports and then searched a freely accessible academic database that includes both peer-reviewed and grey literature. We organized this search by geographical context, adding the keywords "homeless," "homelessness," and "housing" or Danish terms selected to match English terms as closely as possible ("hjemløshed," "boligløshed," "bolig"). We used Google Scholar exclusively and scanned the "cited by" and "related articles" functions to find additional relevant literature.

Third, we read the grey and academic literature to determine what merited inclusion in the review. Our only criterion was that the works must include descriptive or analytical material on homelessness in one of the three geographical contexts. Therefore, we accepted articles that discussed homelessness in an entire country, but included specific data or conceptual material on homelessness in one or more of our three geographical contexts.

Fourth, we analyzed the thematic content of these articles, identifying key themes in the literature according to geographical context. We then compared the main themes across contexts, highlighting both common themes and context-specific themes. In addition, we identified gaps, critical issues, and further research directions across the three geographical contexts.

\section{ALASKA}

Over the past three decades, the population of Alaska has grown from approximately 500000 to 710000 persons (U.S. Census Bureau, 2012). While geographically Alaska is more than twice as large as Texas, in population size it ranks as number 48 of the 50 states. Furthermore, despite rapid population growth in the Anchorage Municipality and the adjacent Matanuska-Susitna Valley, the state remains predominantly rural, with only three major cities: Anchorage (population: 291 896), Fairbanks (31 535), and 
Juneau (31 275) (U.S. Census Bureau, 2012). Only 26 of the state's 352 communities have populations of more than 1000 people. The Alaska government plays a role in affordable housing programs, mainly by providing grant support to municipalities and NGOs. There is also some housing support provided to Alaska Natives through various federal programs. The health care system in Alaska is typical of the rest of the United States, with a focus on health services by private-sector businesses. Some people have health insurance provided by employers, others pay out of pocket for it, and others have no health insurance at all.

At present, the full extent and distribution of the homeless population in Alaska is unknown. Even though homelessness has been a persistent problem in Alaska over the past three decades, the literature on this topic is scanty, consisting of a patchwork of government and NGO reports, municipal and statewide policy documents, and the occasional research study or graduate thesis. In the Alaskan context, homelessness tends to be defined in different ways depending on the government agency or service provider. In a time of increased fiscal constraint and uncertainty at both the federal and state levels, how homelessness is defined has profound implications for the mechanisms used to address it. Moreover, academics and service providers in Alaska generally recognize that people experiencing homelessness may define the term differently from service providers or the broader public (Travis, 1991; Tierney, 2005; McClain-Owens, 2012) and that estimates of the number of people experiencing homelessness, as is true elsewhere in the United States, are likely far below the reality.

The U.S. Department of Housing and Urban Development (HUD) conducts annual Point-In-Time (PIT) counts of sheltered and unsheltered homeless people to determine the allocation of funds and service programs across the nation. Interestingly, HUD's count excludes staying with friends or family or staying in a hotel or motel as a form of homelessness, although the U.S. Department of Health and Human Services (DHHS), which provides funding for school districts to serve homeless children, does include them (Armstrong and Chamard, 2014). This exclusion by HUD is particularly concerning with respect to rural Alaska, where multi-generational households of extended family are common, and individuals who are technically "houseless" may find a place to stay on a couch of a family member. Differences in definitions play a major role in shaping and constraining access to housing support services, particularly in rural regions.

Additional to definitional discord are the logistical challenges of enumerating people experiencing homelessness across the state's more than 300 communities, many of which are classified as rural and remote. To date, no comprehensive research effort has been made to assess the demographics of homelessness in Alaska. Rather, what research has been done has tended to focus on smaller subsets of the homeless population in and around Anchorage. Attempts at enumeration are also hindered by other factors, such as the prevalence of hidden homelessness, homeless people who do not use services, and episodic homelessness.

However, the few existing estimates of the Alaskan homeless population suggest that it is composed largely of women and children (Wilson and Lowe, 2007; Armstrong and Chamard, 2014), Alaska Natives (Travis, 1991; Alaska Council on the Homeless, 2015), with a growing number of youth (Rosay, 2005). According to the 2013 Project Homeless Connect study, women headed 61.6\% of the homeless families surveyed in the 2013 PIT count (Armstrong and Chamard, 2014). Research on women staying in four different shelters in Anchorage found high rates of episodic homelessness, histories of domestic violence, sexual assault, and growing up in (or losing custody of children to) the foster care system. Anecdotal accounts of ethnic discrimination, substance abuse, incarceration, and experiences in the child welfare system were also documented within the Alaska Native homeless population (Travis, 1991).

Some research has attempted to document the ways in which Alaska Native people living with homelessness come to see themselves and their circumstances and how they tack these identities onto their perceptions of the surrounding, largely non-Native, city of Anchorage. For example, Tierney (2005) suggests that behaviors typically seen by the general public as antisocial and as problems in need of fixing, such as public intoxication in small groups, are in fact part of an adaptive survival system that manages (and sometimes reinforces) the harmful stigmas that Alaska Native people living homeless encounter. In particular, such behaviors may permit people to form and maintain social ties and support systems with other Alaska Natives from their home village or surrounding villages.

A 2004 study found that Anchorage youth are more likely to become homeless if they have experienced physical, emotional, or sexual abuse in the family, come from a family experiencing substance abuse, or lived through their parents' divorce, or if they were raised in the foster care system (Rosay, 2005). The needs of vulnerable youth identified in this study include drug and alcohol treatment programs, employment assistance, and safe recreation (Rosay, 2005). Though the circumstances and needs of homeless youth are not unique to Alaska, an increasing number of youth from rural Alaska and Alaska Native youth are using Covenant House Alaska in Anchorage (Martin and Melendez, 2010). A common characteristic among the homeless youth originating from rural areas is the lack of a high school diploma or equivalency (Martin and Melendez, 2010).

\section{Key Themes in the Alaskan Homelessness Literature}

Although they are based on limited research, the patterns of homelessness documented in Alaska appear to be tied to broader geographical flows of people, resources, social upheaval, and poverty. Travis (1991) linked increasing 
homelessness in Anchorage in the 1980s to patterns of rapid social change that occurred in Alaska after the Second World War. Indeed, much of the contemporary geography of Alaska is the result of World War II-era and post-war development, including the construction of the Alaska highway system and widespread military installations, as well as mining and other extractive industries (Howe, 2009). The unequal distribution of wealth, jobs, schools, housing stock, infrastructure, and services across Alaska's urban and rural settlements, some accessible by road and some only by air or water, has emerged from this rapid but uneven development in the 20th century. The literature suggests an uneven geography of access that influences who is at risk of becoming homeless in urban centers in Alaska. For example, Anchorage, as the largest city and the center of the entire healthcare system for the state, pulls in people who have no money or other means to return to their home communities. This fact has been noted within both the adult homeless population and the youth population (Martin and Melendez, 2010). Furthermore, since federal funding is tied to data generated from Alaska's most populous communities, structural inequalities remain that make housing insecurity in rural communities an issue of critical importance (HUD, 2011). For example, voucher programs such as Section 8 (housing choice voucher) are available only in 15 of the more populous communities in Alaska, creating barriers to housing assistance that disproportionately affect rural residents (HUD, 2017).

Howe's (2009) study of rural-to-urban migration in Alaska found the most common types of migration to be intra-regional migration, from village to village and from village to hub town, and hierarchical migration. Hierarchical migration is a stepwise pattern of moving from smaller communities to hub towns and eventually to urban settlements such as Fairbanks or Anchorage, with the occasional next step of moving out of state. Similar stepwise migration patterns of moving between villages, then to hub towns, and eventually to Alaska's larger towns and cities have been observed for those living homeless who end up seeking services in Alaska's largest centers (Armstrong and Chamard, 2014) and also within the homeless youth population (Martin and Melendez, 2010). Other scholars have looked at gendered patterns of rural-urban migration in Alaska and found unique risks that are shaped by age, ethnicity, and educational or career aspirations (Hamilton and Seyfrit, 1994a, b; Seyfrit et al., 1998). Rural-tourban migration and rural and urban experiences with homelessness in Alaska require further investigation.

Homelessness in Alaska (and elsewhere in the circumpolar North) is characterized by unique vulnerabilities and stressful structural conditions, including exposure to cold weather, wildlife encounters, insufficient housing stock, and low vacancy rates. Shelters operate at capacity, and many people are turned away with no other place to go. As a result, death is a fairly regular occurrence among people experiencing homelessness in Alaska, especially during winter, and homelessness is a frequent topic in local media throughout the winter (see Shimer et al., 2014).

The Housing First approach was controversial when it was first introduced in Alaska in 2011 despite its wide recognition as a model for best practice, particularly for people with long histories of homelessness. The controversy was partly due to its central tenet that sobriety or treatment compliance is not a pre-condition for housing (Shimer et al., 2014; Hedwig and Barker, 2016). Alaska's three major cities (Anchorage, Fairbanks, and Juneau) all currently offer project-based Housing First options, although the number of available beds is limited. While the model has proven successful in terms of both harm reduction and housing retention, there is a clear need to expand transitional and permanent supportive housing options in communities across Alaska (Shimer et al., 2014).

Despite their vulnerabilities, people experiencing homelessness in Alaska still actively seek out and construct a sense of home (Hedwig and Barker, 2016). Families are often geographically scattered, yet kinship, both natural and fictive, has been described as of primary importance in meeting everyday survival needs (Hedwig and Barker, 2016). Death of family members is often cited as a reason for family rupture, relocation, and strained relationships. In many cases, family discontinuity is exacerbated by the experience of homelessness (Hedwig and Barker, 2016), in part because family members may lack a consistent place to live with a permanent physical address or a phone that can make long distance calls. Research on early impacts of Housing First in Alaska indicate that simply being housed is an essential first step toward improved quality of life in several key life domains, including physical and mental health, sense of safety, security and well-being, and social connectedness in family and community settings (Shimer et al., 2014). Preliminary results from evaluations of Housing First in Anchorage and Fairbanks have also found that housing can provide a context and opportunity for reconnection with family, as well as a retreat from the harsh conditions associated with northern street life (Shimer et al., 2014).

Significant gaps in our knowledge about homelessness in Alaska persist. A primary issue is the widely acknowledged underestimation of the homeless population because factors related to northern geographical and sociocultural contexts hinder accurate estimation. These factors include the difficulty of estimating hidden homelessness, especially in remote rural communities; a failure to understand how rural-to-urban migration may be linked to homelessness; and lack of information on the diverse kinds of homelessness experienced by Alaska Natives, women, youth, and families.

\section{THE CANADIAN NORTH}

The Canadian North, which for the purpose of this article includes the three northern territories-Yukon, Northwest 
Territories (NWT), and Nunavut - is characterized by vast land areas, relatively small populations, and considerable distances between communities, most of which are connected only by air or water transportation routes. The North became central to Canada's image during the Second World War, when both its resource-rich "hinterland" and its placement along the Arctic coast brought its economic and geopolitical potential to national attention (Abele, 1987). The Canadian government increased its presence in the North largely through settlement and housing policies, which were developed to apply Canadian social welfare to the territories and intended in part to integrate northern peoples through culturally assimilative health and social programming (Tester and Kulchyski, 1994). Since the mid 20th century, the federal government has played a major role in administering, as well as funding, northern housing programs. At present, it funds northern housing initiatives through the Canada Mortgage and Housing Corporation (CMHC); however, the CMHC plans to terminate its support for maintaining social housing in the North by 2036 (Standing Senate Committee on Aboriginal Peoples, 2017). Today, northern territorial governments play a key role in providing public and subsidized housing; however, a decrease in funds from the CMHC places significant stress on the territorial housing corporations.

Homelessness first appeared as a policy issue in the Canadian North in the late 1990s. Across all three northern territories, the consensus from both advocacy and support groups and territorial housing corporations is that homelessness is on the rise (Inuvik Interagency Committee, 2003, 2006; Yellowknife Homelessness Coalition, 2007, 2009; Bopp, 2007a, b; Yukon Housing Corporation, 2009, 2014; Yukon Anti-Poverty Coalition, 2011; Nunavut Housing Corporation, 2013, 2016; NWT Housing Corporation, 2015). Advocacy groups have repeatedly highlighted the lack of adequate and affordable housing across northern communities as underlying the increasing number of Northerners living on the streets, in situations of hidden homelessness, or in emergency shelters. Yet despite the many similarities across the three territories, their distinct geographies result in different experiences with homelessness, which will be explored below.

The 2010 Nunavut Housing Needs Survey concluded that approximately 1220 people across Nunavut did not have a permanent home, one in every two homes fell below national standards (Government of Nunavut, 2010), and $49 \%$ of Nunavut homes were overcrowded. A PIT study in 2014 (see Murphy, 2014) found 57 people living in Iqaluit homeless shelters and 15 others living in various disparate locations; however, these numbers were widely contested as failing to capture the full scope of the issue, which is complicated by the limited number of shelter beds in the city of Iqaluit and a climate that does not permit street sleeping. Moreover, the PIT study really accounted for only the number of available beds at the emergency shelters for men and women and other well-known locations frequented by homeless people in the community.
In Yukon, though no PIT count or comprehensive enumeration effort has been attempted in the capital or in the territory more broadly, it was reported in 2013 that the Whitehorse Salvation Army had sheltered more than 350 unique individual clients in the previous year (Mechan, 2013). In the Northwest Territories, similarly, efforts to assess the rate of homelessness have focused on the capital city. For 2008, the Yellowknife Homelessness Coalition (2009) estimated that almost 936 people (roughly 5\% of the city's population) experienced homelessness at one point or another during that year. However, this number was contradicted in 2015, when the City of Yellowknife (2015:1) embarked on its own PIT count, and found that "a minimum of 139 individuals were experiencing homelessness." The PIT study findings were met with disbelief by support providers in the community, who have argued that homelessness has risen dramatically since the 2008 enumeration by the Yellowknife Homelessness Coalition (Christensen, 2017). That count included only unsheltered, emergency sheltered, and provisionally sheltered individuals, with the acknowledgement that only a small fraction of these categories was really enumerated and that those "at risk" of homelessness were excluded entirely (City of Yellowknife, 2015:2). Of the respondents, 48\% identified as male, $47 \%$ as female, $2 \%$ as transgendered, and $3 \%$ gave no answer (City of Yellowknife, 2015:2). The average age of respondents was 40 (age range: 17 to 77 ), and 91\% of respondents identified as Indigenous (City of Yellowknife, 2015:10). Though many of the respondents indicated either being born in Yellowknife or having lived there for more than 10 years, $54.5 \%$ of them had arrived in the city within the preceding five years, largely from rural locales in the Northwest Territories and Nunavut (City of Yellowknife, 2015:13). Furthermore, $25.9 \%$ of respondents indicated they had most recently been homeless for more than five years, whereas $21.6 \%$ reported having been homeless for six months or less (City of Yellowknife, 2015:15). Accounting for the number of times a respondent had been homeless, the PIT determined that $78 \%$ of respondents would be classified as chronically homeless rather than episodically homeless (City of Yellowknife, 2015:17). In Inuvik, NWT, no official homeless 'count' has been made; however, estimates from support providers suggest that visible homelessness affects 40 to 60 people, roughly $1 \%$ to $2 \%$ of the town's population (Christensen, 2017). More accurate numbers are difficult to obtain, in part because the focus on homelessness in Yellowknife has produced a relative policy blindness to the issue outside the capital region, and in part because services for the homeless in Inuvik are severely lacking, making it difficult to know who would be using those services were they to exist (Young and Moses, 2013).

Anecdotal accounts provided across the three territories indicate that hidden forms of homelessness, particularly couch surfing, are even more pervasive than visible homelessness, especially outside urban locales (Webster, 2006; Bopp, 2007a, b; Lauster and Tester, 2014; City of Yellowknife, 2015). Within those urban locales, studies have 
shown that people living homeless engage in innovative strategies, such as constructing makeshift tents, camps, and sleeping in warm stairwells or utilidors (insulated aboveground water and sewage lines) to find warmth and shelter (Tester, 2006; Westfall, 2010; Christensen, 2017). This is particularly the case among those men, women, and youth who cannot (or for various reasons will not) access space in emergency shelters. Research has also shown that RCMP holding cells in Whitehorse, Yellowknife, Iqaluit, and Inuvik are used as de facto shelters in those communities because existing shelters lack adequate beds and some have a sobriety requirement (Christensen 2012, 2017; Mechan, 2013; Nunavut Housing Corporation, 2013; Young and Moses, 2013; Young, 2016). The prevalence of hidden forms of homelessness, combined with other coping strategies, adds to the difficulty of assessing homelessness in the North.

\section{Key Themes in the Canadian North Homelessness Literature}

Chief among key themes in the homelessness literature on the Canadian North is the high rate of core housing need among households in rural and urban communities. Core housing need, a standard measure of housing insecurity in Canada, includes affordability, adequacy, and suitability of both private market and public housing stock. Across all three territories, private market housing tends to be concentrated in regional or urbanizing centers, whereas smaller communities tend to be more reliant on publicly subsidized housing options. Though overcrowding in public housing is a reality in Yukon and the Northwest Territories, it is undeniable that residential crowding is most significant in Nunavut. In fact, Lauster and Tester (2014) suggest that homelessness in Nunavut is characterized not by people sleeping in the streets, but by extraordinarily high levels of residential crowding.

In northern urban or regional centers, as Westfall (2010) and Falvo (2011a, b) suggest, increasing unaffordability in the private rental market, combined with a limited number of public housing units, has led to a particularly bleak picture of low-income housing availability. Schmidt et al. (2015) identify the shortage of housing as a critical factor in the incidence of homelessness in Canada's North, citing in particular the very low rental vacancy rates in the larger centers. Mechan (2013) argues that Whitehorse is undergoing a housing crisis, with very low vacancy rates in private rental accommodation and long waiting lists for public and social housing; moreover, while rents increase in the city, income levels have not increased proportionately, particularly for those who earn minimum wage or access social assistance.

Reports from the Yukon Housing Corporation (2009, 2014), the Northwest Territories Housing Corporation (2008, 2015, 2016), and the Nunavut Housing Corporation $(2012,2013,2016)$ recognize the central role that social or public housing plays in the prevention of homelessness. At the same time, three territorial government reports from the Nunavut Housing Corporation (2012, 2013, 2016) highlight challenges related to land development, community planning, and capital planning and infrastructure coordination that create additional barriers to increasing the supply of northern housing. They link these challenges to the legacy of underinvestment in the territory's infrastructure, the ongoing bureaucratic and financial challenges related to northern community planning, and the sporadic nature of northern housing investment from the federal government.

Research also suggests that rural-to-urban movement plays a significant role in northern homeless geographies and experiences. Northern settlement geography in combination with uneven economic and infrastructural development and the uneven concentration of key institutional services in larger centers contributes to distinct patterns of rural-to-urban movement in the lives of northern homeless people. While homelessness in the Canadian North is often portrayed as an issue confined to larger centers, many northern residents experiencing homelessness in northern cities and towns originate from small, rural settlement communities. Christensen (2012) suggests that uneven and fragmented social, institutional, and economic geographies result in a unique landscape of vulnerability to homelessness in the Canadian North. Writing about the Nunavut context, Tester $(2006,2009)$ cites the implementation of flawed northern settlement plans and the introduction of inadequate northern housing as principal factors in the high rates of unemployment and housing need in northern communities, two factors which he argues are significant contributors both to hidden forms of homelessness in small settlement communities and to the migration to larger centers of Northerners vulnerable to homelessness. In the Yukon, Mechan (2013) suggests that it is common for individuals to arrive from rural communities to attend medical appointments, shop, or connect with services and then find themselves without transportation back home. Similarly, individuals from rural communities are often discharged from the correctional centers in Whitehorse, Yellowknife, Fort Smith, and Iqaluit without adequate planning to reconnect them with the supports in their home community (see also Christensen, 2012). As a result, they end up homeless in the larger northern centers.

Another factor framing the significance of rural-tourban movement in northern homeless geographies is that emergency shelter services in the Canadian North are limited to the larger, urbanizing centers, and even there, the number of emergency shelter options is very small. Emergency shelters across the three capital cities function more as long-term accommodation rather than as shortterm, emergency housing, with reports of clientele staying in shelters for upwards of five years (Christensen, 2011; Mechan, 2013). This situation has to do, in large part, with the lack of available, affordable housing and effective support services for those Northerners with mental health concerns, substance abuse, or other factors that limit their 
access to sustainable employment and housing. Young and Manion's (2017) study on a pilot emergency warming center project in Inuvik highlighted the lack of suitable infrastructure - a distinct challenge across the Canadian North - as a major barrier to addressing the various intersecting factors in northern homelessness. They suggest that the efficacy of such programs is severely handicapped by a lack of "next step" options in terms of supportive housing or treatment opportunities available to support a longer-term transition out of homelessness. Currently in the Canadian North, the only Housing First programs in operation are found in Yellowknife (Christensen, 2017).

One of the most disturbing characteristics of homelessness in the Canadian North is the high representation of Indigenous peoples. Research from all three territories reports higher incidences of homelessness amongst Indigenous peoples than in the rest of the population. In fact, the Yukon Anti-Poverty Coalition (2011) found that respondents to their homelessness survey who self-identified as Indigenous were 3.9 times as likely to be homeless as those who did not, while Christensen's research (2011) in the NWT found anecdotal evidence that $90 \%-95 \%$ of those people living homeless were Indigenous. These findings speak to a higher incidence of poverty and core housing need among Indigenous peoples. Racism in the housing and employment markets and in government services are also reported in Whitehorse (Yukon AntiPoverty Coalition, 2011) and Yellowknife (Christensen, 2017). Research points to the combined effects of colonial settlement and social policy and the intergenerational impacts of colonialism on Indigenous peoples, as well as the specific role that these geographies play in framing homelessness amongst Indigenous Northerners (Tester, 2006; Christensen, 2013, 2016; Lauster and Tester, 2014). The intergenerational impacts of colonialism are tied to the prevalence of racism experienced by Indigenous peoples, as well as poor mental health, addictions, family violence, fetal alcohol spectrum disorders, children in foster care, and incarceration, all of which can contribute to homelessness (Bopp, 2007a, b; Minich et al., 2011; Badry and Felske, 2013a, b; Christensen, 2013, 2016; Young and Moses, 2013). Yet there is a drastic shortage of culturally appropriate and community-based mental health and addiction treatment services in the North, even in larger communities (Christensen with Andrew, 2016; Christensen, 2017).

Women, like Indigenous peoples, are also overrepresented among those experiencing homelessness in the Canadian North. Schmidt et al. (2015) estimate that upwards of 1000 women are homeless across the three northern territorial capital cities. For homeless women in particular, trauma and family violence are significant factors framing the personal life crises that combine with housing insecurity to lead to homelessness (Bopp, 2007a, b; Schmidt et al., 2015). A key challenge in addressing northern women's homelessness is that, according to Schmidt et al. (2015), most northern homeless women are not living rough, but rather fall within the "hidden homeless" category.

Inappropriate northern housing policy has also been identified as contributing to northern homelessness. The historical implementation of housing policy that did not reflect the realities and needs of northern families and communities set the stage for inconsistent, inappropriate, and inadequate housing policy and provision that persist to the present day (see Lauster and Tester, 2014). Christensen (2011) and Young and Moses (2013) also argue that the punitive nature of northern housing policy is a significant factor in homelessness, particularly in light of inadequate public and private housing and the absence of appropriate mental health and addiction treatment options. Several studies (Lauster and Tester, 2014; Schmidt et al., 2015; Christensen, 2016) call for a fundamental rethinking of service interventions to shift from stigma to respect for the resiliency and goals of men and women living homeless. Since 2012, both the Northwest Territories and Nunavut governments have allotted new funding for services related to mental health and addiction and for new programming that emphasizes community-based and culturally appropriate health and wellness resources. The move towards culturally safe approaches to mental health points to an opportunity to engage in similar development towards the inclusion of Indigenous approaches to health and wellbeing within the scope of transitional housing as well as in public housing policy.

Ill-suited definitions or understandings of homelessness, in both northern and Indigenous contexts, also contribute to a disconnect between culture and policy. Lauster and Tester (2014) argue that the way in which the lack of housing in Nunavut affects people is not quite the same as the way the housing crisis is measured by estimates of core housing need. For example, those in core housing need are often treated as being at risk of homelessness, they argue, whereas in actuality they are already experiencing multiple dimensions of homelessness. In addition to shelter and security, experiences of homelessness among northern Indigenous peoples speak to a profound sense of exclusion connected to a lack of access to land, a lack of cultural pride and identity, and the absence of a sense of purpose within one's community (Christensen, 2013; Lauster and Tester, 2014; Poole and Bopp, 2015).

\section{GREENLAND}

Greenland is the world's largest island, covering an expanse of more than two million $\mathrm{km}^{2}$ and stretching from Cape Farewell in the south to Oodaq Island in the high North. Politically, Greenland is governed under Self Rule, which means that it is still considered part of the Danish Realm but has autonomy over central governmental activities such as social policy, education, health, economy, and housing. The majority of Greenland's 56000 inhabitants live on the country's west coast. About $90 \%$ of 
the population is Greenlandic (Inuit) while the remainder is mainly Danish (CIA, 2017). While Greenlandic is the official language, Danish is also widely spoken throughout the country (CIA, 2017). Greenland has universal health care and is considered a welfare society following the Scandinavian model; taxpayers pay close to half their income in taxes in exchange for a wide spectrum of publicly administered services.

Framing the landscape of housing insecurity and homelessness in Greenland is the country's geography of settlement and rural-to-urban mobility. Over the early to mid 20th century, while Greenland was entirely under Danish control, the Danish state actively pursued the concentration of Greenlandic people in permanent settlements (Dahl, 2010; Sejersen, 2010). In some cases, this occurred through the actual closure of smaller settlements (Dzik, 2016). Modern apartment blocks with sanitation, electricity, central heating, and larger indoor spaces were part of a broader modernization project in Greenland from 1950 to 1980 (Rosing Olsen, 2005). Established by Danishorganized political committees with little appreciation for the needs and wants of Greenlandic society, the new housing and development plans emphasized high-density housing programs in regional centers alongside the expansion of social welfare services, which included the implementation of public health programs, education, and income support (Rosing Olsen, 2005).

Though such plans were enacted to promote Greenlandic participation in the wage economy and facilitate administration by the colonial state, they also had profound social and spatial implications. Centralization policies put into motion a distinct rural-urban geography in Greenland, which in recent decades has become increasingly focused around urban centers, such as Ilulissat, Sisimiut, Nuuk, and Qaqortoq. There is evidence to suggest a general demographic movement from smaller settlements (translates to nunaqarfik in Greenlandic, the place where nature is) to small towns, and finally to larger towns or cities (translates to illoqarfik in Greenlandic, the place where the houses are) such as Sisimiut (North Greenland), Qaqortoq (South Greenland) and Nuuk (the capital in the middle of Greenland) (see Rasmussen, 2010).

Rental housing in Greenland is largely administered in one of two ways: through public housing or through publicsector employment. To access public housing, which is administered by Greenland's public housing authority, INI (Inatsisartut Inissiaatileqatigiifik), one can add one's name to the housing list starting at age 18. These waiting lists, however, can be incredibly long. In Nuuk, for example, it can take upwards of 15 years to get an apartment on one's own. Meanwhile, certain jobs within the public sector (i.e., teacher, nurse, university professor) come with apartment assignments. As long as one maintains the post, one gets to keep the assigned rental apartment. Alternatives to the public housing waiting list include 1) getting an education in order to find a job with an assigned apartment or 2) purchasing a private house or apartment, which tend to be both expensive and in short supply. Thus, the Greenlandic housing landscape can be highly problematic for those Greenlanders who do not have adequate education or employment.

Media reports on homelessness began to appear first in the 1990s; however, they remained largely focused on Nuuk (Kleist, 1997). Though the scope of media attention widened in the early 2000 s to include homelessness in smaller communities, there are still no public figures available on the number of homeless people countrywide. This lack is due in part to the absence of a standardized definition of homelessness in Greenland, which makes it difficult to assess who is homeless and to draw meaningful comparisons between different communities. Difficulty defining homelessness in Greenland, combined with a common perception of homelessness as a typically urban issue, also contributes to the lack of national figures. Homelessness as a Greenlandic social policy issue is, with few exceptions, presented as a predominantly urban, and largely Nuuk-centered, phenomenon (Arnfjord and Christensen, 2016). Another related factor is the subtle administrative process of prioritizing public housing in the larger urban cities, mainly Nuuk (Hendriksen, 2013).

The academic and grey literature on the topic of homelessness in Greenland began to develop in the early 2000 s, and it remains limited. Furthermore, this research has more or less focused on the larger Greenlandic cities such as Sisimiut (pop. 7000) and Nuuk (pop. 17000). A short 20-page study from 2008 titled "Hjemløs i Grønland" (Homeless in Greenland), commissioned by the Greenlandic Ministry of Family and Health, provides a first overall look at the Greenlandic homeless situation (Departementet for Familie og Sundhed, 2008). Inspired by an earlier Danish study on homelessness (Benjaminsen and Christensen, 2007), the report begins with a broad, seven-point definition of homelessness ranging from people without a roof over their heads, to people living in hotels or hostels because they are homeless, to people living in psychiatric or residential care institutions awaiting to be released within a three-month period. The only data collection method employed by the study was a questionnaire distributed to all 17 municipalities requesting data from the public offices on the number of people in their respective jurisdictions without a documented permanent residence. These data were then divided into three groups: men, women, and adults with children. Unfortunately, the level of municipal reporting is inconsistent, with some municipalities not reporting at all, or others reporting without specific data on gender or household composition. An additional oversight in the report is that, inexplicably, the capital Nuuk is omitted entirely. The report found that in 2008 a total of 514 people were living homeless countrywide; however, the missing number from Nuuk limits the overall applicability of its findings. Nevertheless, the report continues with a statistical analysis of the 514 people, the majority of whom were found to be between the ages of 20 and 60 years old. Of this group, $20 \%$ were 
employed and $40 \%$, according to the municipalities, had problems with substance abuse. The report provides some qualitative feedback from the municipalities, several of which stated that household overcrowding is exacerbated when a family is obliged to take in a relative who has no alternative but to live with them because of the lack of sufficient housing. Ongoing initiatives such as night shelters, shipping container housing, and women's shelters were all described as only short-term solutions. The report concludes that homelessness in Greenland is not only a matter of unemployment, material poverty, or housing insecurity, but rather tightly intersects with trauma and other psychological issues, addiction, domestic violence, and other forms of abuse (Departementet for Familie og Sundhed, 2008).

In 2013, a more comprehensive study, entitled "Hjemløshed i Grønland" (Homelessness in Greenland), was published by Statens Byggeforskningsinstitut (The Institute for Danish Housing Research) at Aalborg University (Hansen and Andersen, 2013). The report uses three main categories to conceptualize homelessness: a) "homeless," which includes those without a fixed place to have shelter for the night, b) "houseless," which includes those living temporarily with relatives or friends but without a house of their own; and, c) "rehoused," which includes those living in a halfway house because they are in debt to the public housing organization INI or Iserit (a public municipal housing organization located in Sermersooq, the Nuuk capital region). The authors gathered data by visiting several municipalities in Greenland and using mixed methods such as statistics, photography, and qualitative interviews conducted in Greenlandic by a social worker.

The report makes two significant contributions to our understanding of Greenlandic homelessness. Firstly, there are valuable insights into the biographies of people living under homelessness via interviews conducted in their native language. The interview data also document the existence of vast social issues connected to homelessness in Greenland, such as abuse, problematic upbringing, poor social resources, unemployment, and so on. Secondly, a critical linkage is established between the housing situation in Greenland, characterized in particular by chronic housing need, and the emergence of homelessness. For example, the housing stock in Greenland consists mainly of public housing, some of which is in poor condition or located in communities where employment, educational, and cultural opportunities are in decline. Young people in these communities are forced to seek these opportunities in regional urban centers or beyond. Hansen and Andersen's (2013) report also reveals an increase in evictions from public housing between 2005 and 2013, which were due largely to increasing enforcement of rent and housing rules in light of diminishing housing stock.

Though its scope is wide, the 2013 report was government-funded with the task of describing the field and providing a baseline for further action towards reducing homelessness (Hansen and Andersen, 2013:25), and it is therefore more a descriptive, administrative report than a critical or solution-oriented document. Moreover, tenants, citizens, and people experiencing homelessness are essentially portrayed as objects that react to the whims of the housing or social system. By providing only a descriptive analysis of homelessness in Greenland, the report does little to advance real, action-oriented change.

The 2013 report cites a conservative estimate of approximately 600 people living homeless in Greenland as a whole (Hansen and Andersen, 2013:24). This estimate includes shorter homeless periods ranging from days to a few weeks; however, it says little about homelessness as a more chronic situation. In the capital city of Nuuk, the conservative estimate of people living under a more permanent state of homelessness is 100-200 (Departementet for Familie og Sundhed, 2008; Hansen and Andersen, 2013). Recent research by Arnfjord and Christensen (2016) on homelessness in Nuuk has resulted in anecdotal evidence from NGO-based support providers that the number of homeless individuals in Nuuk alone is roughly 250-300 people.

Research by Arnfjord and Christensen (2016) has uncovered four main groups of homeless people in Greenland: 1) men over 30 years of age with addictions and without a place to live; 2) youth with family, social, or economic problems who migrate from small settlements to larger centers in hope of new opportunities; 3 ) women who either are single or no longer have custody of their children, and who have often been victims of domestic violence; and 4) men and women over 55 who have been evicted from their housing after failure to pay rent.

Curiously, Arnfjord and Christensen (2017) have found that homeless women are a particularly neglected group in the spectrum of Greenlandic social policies and services. The first women's shelter in Greenland was built in the capital, Nuuk, in the late 1970s (Jensen, 1982; Vammen, 2003). That initiative came from Kristelig Forening for Unge Kvinder, a Christian NGO, which is now part of the YWCA (Young Women's Christian Association). Despite evidence to suggest that homelessness among women in Greenland is a concern, it has not been possible to locate a specific research focus on women living homeless. Raadet for Socialt Udsatte (The Authority for the Socially Marginalized) has previously declared that women constitute one of the most vulnerable groups of people living with homelessness (Raadet for Socialt Udsatte, 2016). Yet Nuuk does not have specific strategies aimed at securing a safe shelter for women in marginalized situations, despite approximately 750 reports of domestic disturbances in the city annually (Grønlands Politi, 2016). Though there is support for mothers with young children and elderly women, very little exists for single women or women living in or leaving violent relationships (Poppel, 2016). 


\section{Key Themes in the Greenlandic Homelessness Literature}

Numerous themes can be found in the literature on homelessness in Greenland. Uneven rural-urban geographies, intergenerational impacts of colonialism, and social welfare dependency have been observed in the context of homelessness in Greenland (Hansen and Andersen, 2013). Many of these themes are directly related to critical social issues visible within Greenlandic welfare society today, including a rise in the number of children facing social problems (Skatte- og Velfærdskommissionens betænkning, 2011; Pedersen and Bjerregaard, 2012) and violence against women (Fievé and Hansen, 2016; Poppel, 2016; Raadet for Socialt Udsatte, 2016). These issues receive significant political and media attention for obvious and important reasons. Underneath these immense challenges is the escalation in homelessness. In fact, housing insecurity has been identified as a critical element in violence against women in Greenland (Poppel, 2010). Yet curiously, homelessness is not a prioritized social political issue in Greenland.

Another general factor that individualizes social problems is the overall focus on alcohol abuse and its causal linkage with neglect, violence, and evictions. The social dynamics of alcohol dependence have received significant research attention (Udvalget for Samfundsforskning i Grønland, 1960; Wagner Sørensen, 1999). The result is that this research represents social problems as occurring at the scale of the individual, rather than highlighting the sociostructural processes that contribute to their reproduction and ultimately to homelessness. More academic and community-based research into the linkages between individual and socio-structural factors in Greenlandic homelessness is necessary.

The literature on Greenlandic homelessness, though sparse, touches on the dynamics of social marginalization, but very little literature explicitly conceptualizes homelessness in Greenland within its specific geographical, cultural, or social context. For example, research suggests that rural-to-urban and Greenland-to-Denmark migration is a significant factor in Greenland homeless geographies (see Hansen and Andersen, 2013), yet the dynamics of rural-to-urban mobility and their role in Greenlandic homelessness have not been well explored. In Rasmussen (2011), a representative 1550 people were surveyed on the motivations behind their rural-to-urban move. Top responses included education and employment, living conditions, social network, leisure opportunities, and access to public services (Rasmussen, 2011). Furthermore, the majority of Greenlanders engaging in a rural-to-urban move were young people between the ages of 15 and 25 (Rasmussen, 2010), which reflects a similar observation by Hansen and Andersen (2013) that youth at risk of homelessness were likely to engage in such a move.

One further step or strategy is for people to leave the country entirely to seek better fortunes within the Danish
Realm (which includes the Faroe Islands). This typically means traveling to Denmark, where Greenlanders hold citizenship, and where more than 14000 Greenlanders currently reside (Baviskar, 2015). Yet this kind of move does not always mean a brighter future. Recently, the Danish Council of Social Marginalization released a follow-up to a previous report on Greenlandic women living homeless in Denmark (Raadet for Socialt Udsatte, 2016). The report describes problematic conditions for these women, such as language barriers, issues with access to education and employment, and disempowered social networks. Thus far, there has been little joint effort between Greenland and Denmark to offer public help to or safeguard the homeless Greenlandic women in Denmark, leaving them in the care of local Danish NGOs (Arnfjord, 2016).

Several signs suggest that homelessness in Nuuk is on track to increase over the coming years. Employment and educational opportunities, as well as cultural activities, are increasingly concentrated in the capital city. The municipality of Sermersooq, which includes Nuuk, is allocating more land for housing, but not for the low-income groups. Early in 2016, the municipal social council in Nuuk voted down a proposal to convert used migrant worker housing made from shipping containers into transitional housing (Dollerup-Scheibel, 2016). One hypothesis for the rejection is that politicians feared that such a plan would upset families who did not yet have a residence of their own. The political vote in Greenland appears very much tied to children and family welfare, and less to the socially marginalized. There is currently no clear national or municipal strategy to address homelessness in Greenland.

A principle in Greenland's democratic welfare society is that the people affected by political decisions are given a chance to voice their concerns through public forums. However, in recent years there has been a shift in the political climate towards the kinds of neoliberal, marketoriented policies seen in Alaska and increasingly in the Canadian North, and decision making about housing policy is evolving within the political environment with no public hearings. Despite the fact that Greenland does have a small organization of homeless people (see Rørdam, 2016), people living under homelessness are rarely included in development of policy, such as the policy that governs the daily operations of the public shelter in Nuuk.

On the other hand, a positive trend visible in the landscape of Nuuk homelessness is the growing number of NGOs involved in addressing the dynamics of social marginalization in the city. Local NGOs collaborate with one another to provide services to people living homeless in Nuuk, and they also express a common agenda to empower people living under homelessness and provide facilities for people within the environment to voice their concerns. Some initial research has been conducted on the developing individual and collective actions of Nuuk NGOs, although it is still at an early stage (Arnfjord, 2015). 


\section{A DISTINCT NORTHERN GEOGRAPHY OF HOMELESSNESS?}

A unique, northern geography of homelessness is visible across Alaska, Canada's North, and Greenland. Cold climates make daily survival a network-dependent assignment for people living under homelessness in the northern regions. Yet beyond climate, this northern geography of homelessness is indelibly tied to the settlement and colonial histories of each of these regions, as well as to the contemporary landscape of remote rural settlements, hub towns, and larger urban centers. Northern homelessness also appears to be unique because of the particular ways in which people and resources flow unevenly between urban and rural settlements. Yet research on the ways in which rural-urban unevenness and migration contribute to northern homelessness remains limited, particularly in Alaska and Greenland. The urban concentration of the health and social services, criminal justice system, emergency shelters, economic opportunities, and friendship and kinship networks upon which Northerners at risk of homelessness are particularly dependent, all shape the rural-to-urban migration of these Northerners. The often limited (and expensive) transportation routes mean that such mobility is more often than not a one-way move to the town or city. Significantly, the literature also demonstrates that northern regional centers are not the only urban locales important to Northerners at risk of homelessness. Larger urban centers in the southern United States, southern Canada, or (in the case of Greenland) Denmark are also inextricable nodes within the broader geography of northern homelessness.

Within this northern geography of homelessness, there is a diversity of experiences, some of which are specific to context. Though housing is clearly a market commodity in Alaska, in the Canadian North the approach is somewhat mixed, though the drop-off in annual federal funding for northern housing has shifted the northern housing landscape in a similar, market-oriented direction. This shift may be contributing to the development of more punitive housing policies noted by Christensen $(2009,2012)$ and Young and Moses (2013). In Greenland, housing is viewed as a matter of public responsibility. The limitations of this responsibility, however, are revealed in the absence of housing policy directed specifically towards the Greenlandic homeless population. The increasing reliance on NGOs for social support also indicates a shift in the scope of social policy in Greenland. In the Canadian North and Greenland, a trend towards neoliberal or punitive housing policies, reduced government spending on public or social housing, social policies that prioritize urban areas, and insufficient or ineffective mental health and addiction services exacerbate northern conditions that contribute to homelessness.

It is important to note that while homelessness and housing insecurity are receiving a growing amount of treatment by researchers, policymakers, and NGOs in the
Canadian North, there is relatively less literature available addressing the Alaskan and particularly the Greenlandic contexts. This discrepancy significantly challenges our ability to comprehensively compare and contrast these three jurisdictions. Furthermore, across all three contexts, there are differing definitions of homelessness which add to the unique geographical and situational challenges of comprehensively assessing the scale and scope of northern homelessness. Discrepancies in the definitions of homelessness employed by policymakers, NGOs, and various levels of government make it exceedingly difficult to draw a clear picture of the number of people living homeless and the extent of homelessness across the North, as well as to compare demographics between regions.

There are also significant difficulties in defining homelessness to include important cultural and sociostructural dynamics. For example, the prevalence of hidden homelessness, including couch surfing and overcrowding, is a wide-reaching component in the overall northern homelessness spectrum. The contribution that chronic housing need makes to northern homelessness, and the ways in which it renders northern homelessness qualitatively distinct, cannot be overstated. At the same time, the lack of a definition or understanding of homelessness that comes from the very men, women, youth, and families deemed "homeless" is a significant barrier to developing and implementing policies and programs that are appropriate and effective.

Challenges in defining homelessness in northern contexts are compounded by universal difficulties in adequately quantifying homelessness, difficulties that are exacerbated by northern settlement geographies that place communities at a significant distance from one another. The literature reviewed here suggests that chronic housing need, as well as other compounding issues such as limited employment and educational opportunities and social determinants of ill health in northern settlement communities, are inextricably linked to the factors contributing to homelessness in northern urban centers. Yet PIT counts and other efforts to quantify homelessness in northern urban locales largely neglect the significance of rural-urban dynamics in northern homeless geographies.

Those affected by homelessness differ somewhat across the three northern contexts. In Alaska, urban homelessness afflicts a broad range of residents and in many ways reflects the trends in homelessness documented in larger urban centers in southern Canada and the United States. Much less is known about homeless experiences in rural Alaska, but these settlements are similar in many regards to northern Canadian and Greenlandic settlements, particularly because rampant chronic housing shortages and the resulting overcrowding exist in all three contexts. In Alaska and northern Canada, Indigenous peoples are overrepresented among the homeless; however, the availability of data differs considerably, so it is difficult to make a sensible comparison of the extent of the problem in Indigenous populations between the two regions. 
Northern settlement geographies that have politically and economically disadvantaged Indigenous peoples, intergenerational impacts of colonialism, discrimination against Indigenous peoples in the housing and employment markets, and social determinants of ill health all contribute to homelessness among northern Indigenous people. In Greenland, where the vast majority of the population is Greenlandic, the rate of Indigenous overrepresentation is less pronounced, yet homelessness is nevertheless a phenomenon that quite clearly affects native Greenlanders more than it affects the more transient Danes, who often have social and economic resources at home in Denmark.

It is clear across the three contexts that homeless experiences are significantly gendered, however the attention paid to the ways in which gender frames not only the factors contributing to homelessness but also women's encounters with support services and other resources varies significantly according to context. As illustrated in the Greenland section, gender and in particular the experiences of single women have been largely neglected by researchers and policymakers. However, we can see from the broader literature on homelessness that gender frames homeless experiences in all contexts (see Klodawsky, 2006). How gender plays a role in a distinct northern geography of homelessness is perhaps related to 1) high rates of overcrowding and housing insecurity in northern communities, 2) higher rates of intimate partner violence in the three northern contexts, and 3) ruralurban disparities in support resources for women, who often require a rural-to-urban move in order to access shelters for victims of domestic violence, follow children who have been apprehended by the child welfare system, access housing and employment options, and gain access to required resources to support health and wellbeing.

Their chronic nature makes homelessness and housing insecurity persistent issues across the North. High costs of construction and housing maintenance, low vacancy rates, high income inequality, and significant pressure on a very limited public housing stock have meant that anyone who struggles with low income, poor mental health, addictions, or other forms of personal life crisis is at risk of becoming homeless. The high rates of chronic homelessness in the North reflect northern housing insecurity, limited transitional housing options, and the lack of adequate or appropriate supports for people experiencing mental health and addiction issues. Northern regions need housing strategies that specifically aim to add stock at various critical points along the housing spectrum, and this idea has recently gained some footing in Alaska, Yukon, and the Northwest Territories through Housing First and transitional or supportive housing programs. Yet even here, these options are concentrated in larger urban centers, and are limited both in number and in the spaces available for occupants.

While this literature review suggests that there is indeed a northern geography of homelessness, further research is required in order to develop a comprehensive conceptualization of northern homelessness, meaningfully compare experiences across the three northern regions, and highlight best practices in policy and programming for northern people living homeless. In order to develop and implement an effective continuum of care, further research is also needed on northern cultural approaches to homelessness, culturally embedded programs and supports for people living homeless, and the rural-urban health and housing support needs of Northerners at risk of homelessness.

Currently, quantitative and qualitative data on the demographics of housing insecurity and homelessness differ across the three contexts, making comparisons of these experiences difficult, while also obscuring the translatability of policy and program innovations. In all three regions, policy approaches to homelessness are largely guided by definitions applied in more urban, southern settings, which tend to neglect the ways in which northern social, cultural, economic, and settlement geographies contribute to homelessness. Therefore, the absence of an agreed-upon definition of northern homelessness not only prevents accurate cross-contextual comparisons, but also leads to disconnects between policy and real, lived experiences. While region-specific variations must be considered, an overarching definition of what homelessness is in a northern context would be incredibly useful as a research, policy, and advocacy tool. Such a definition would also provide the conceptual foundation for more inclusive methods that go beyond PIT counts in order to account for northern residents at various points of the homelessness spectrum and in various northern locales. For example, housing insecurity data (i.e., rates of core housing need), data on reports of domestic violence, in-depth qualitative interviews with research participants experiencing hidden and visible forms of homelessness, focus groups with support workers, emergency shelter and transitional housing counts, combined with enumeration efforts like PIT counts and conducted in both the summer and winter seasons, would more accurately portray the dynamics and demographics of northern homelessness.

\section{ACKNOWLEDGEMENTS}

Julia Christensen would like to thank Det Frie Forskningsråd (Project No. 13323) for funding her contribution to this research. Travis Hedwig would like to thank the Alaska Mental Health Trust Authority and the Alaska Housing Finance Corporation for funding the evaluation of Housing First and other Permanent Supportive Housing Initiatives in Alaska. All authors would like to thank local housing and homelessness organizations advocating for improved northern housing conditions. 


\section{REFERENCES}

Abele, F. 1987. Canadian contradictions: Forty years of northern political development. Arctic 40(4):310-320. https://doi.org/10.14430/arctic1788

Alaska Council on the Homeless. 2015. Alaska's plan to end long term homelessness. Anchorage, Alaska: Alaska Council on the Homeless. http://www.sectioneightapplication.com/apply/AK

Arksey, H., and O’Malley, L. 2005. Scoping studies: Towards a methodological framework. International Journal of Social Research Methodology 8(1):19-32. https://doi.org/10.1080/1364557032000119616

Armstrong, B., and Chamard, S. 2014. The homeless: Who and how many? Alaska Justice Forum 31(1-2):2-11.

Arnfjord, S. 2015. Social udsathed og tuberkulose i Nuuk [Social marginalization and tuberculosis in Nuuk]. Tikiusaaq 2(23):20-24.

- 2016. Sociale udfordringer hos et mindretal af grønlandske kvinder $\mathrm{i} \mathrm{DK}$ skal håndteres $\mathrm{i}$ (Rigs)fælleskab [Social challenges concerning a minority of Greenlandic women in Denmark need to be handled within the Realm]. København: Socialpolitisk Forening.

Arnfjord, S., and Christensen, J. 2016. Understanding the social dynamics of homelessness in Nuuk, Greenland. Northern Notes 45:4-5.

http://iassa.org/images/newsletters/Northern-Notes-Issue-45Spring-Summer-2016.pdf

- 2017. De søger trygheden: Kvinder ramt af hjemløshed i Nuuk [They are seeking safety: Women hit by homelessness in Nuuk]. Psyke \& Logos 38(1):23-33.

Badry, D., and Felske, A. 2013a. Exploring the prevention of fetal alcohol spectrum disorder in the Northwest Territories of Canada: Brightening our home fires. The International Journal of Alcohol and Drug Research 2(3):7-15. https://doi.org/10.7895/ijadr.v2i3.125

- 2013b. An examination of three key factors: Alcohol, trauma and child welfare: Fetal alcohol spectrum disorder and the Northwest Territories of Canada. Brightening our home fires. The First Peoples Child \& Family Review 8(1):130-142.

Baviskar, S. 2015. Grønlændere i Danmark : En registerbaseret kortlægning [Greenlanders in Denmark: A census-based mapping]. Copenhagen: SFI.

https://www.sfi.dk/publikationer/groenlaendere-i-danmark $-2881 /$

Becker, G. 2015. Healthcare utilization analysis for Housing First program in Anchorage, Alaska. Master of Public Health thesis, University of Alaska, Anchorage.

Benjaminsen, L., and Christensen, I. 2007. Hjemløshed i Danmark 2007: National kortlægning [Homelessness in Denmark 2007: A national mapping]. Copenhagen: SFI.

https://www.sfi.dk/publikationer/hjemloeshed-i-danmark $-2007-5480 /$

Bopp, J. 2007a. You just blink and it can happen: A study of women's homelessness north of 60. Cochrane, Alberta: Four Worlds Centre for Development Learning. 2007b. The little voices of Nunavut: A study of women's homelessness north of 60. Cochrane, Alberta: Four Worlds Centre for Development Learning.

Christensen, J. 2009. Everyone wants to have a place: Homelessness, housing insecurity and housing challenges for single men in the Northwest Territories, Canada. Congress on Circumpolar Health: Proceedings of a conference held 11-16 July 2009, Yellowknife, Northwest Territories. No. 7. 56-59.

—. 2011. Homeless in a homeland: Housing (in)security and homelessness in Inuvik and Yellowknife, Northwest Territories, Canada. PhD thesis, McGill University, Montréal, Québec.

—. 2012. "They want a different life": Rural northern settlement dynamics and pathways to homelessness in Yellowknife and Inuvik, Northwest Territories. The Canadian Geographer/Le Géographe Canadien 56(4):419-438. https://doi.org/10.1111/j.1541-0064.2012.00439.x

_ 2013. 'Our home, our way of life': Spiritual homelessness and the sociocultural dimensions of Indigenous homelessness in the Northwest Territories (NWT), Canada. Social \& Cultural Geography 14(7):804-828.

https://doi.org/10.1080/14649365.2013.822089

— 2016. Indigenous housing and health in the Canadian North: Revisiting cultural safety. Health \& Place 40:83-90. https://doi.org/10.1016/j.healthplace.2016.05.003

- 2017. No home in a homeland: Indigenous peoples and homelessness in the Canadian North. Vancouver, British Columbia: UBC Press.

Christensen, J., with Andrew, P. 2016. "They don't let us look after each other like we used to": Reframing Indigenous homeless geographies as home/journeying in the Northwest Territories, Canada. In: Peters, E.J., and Christensen, J., eds. Indigenous homelessness: Perspectives from Canada, Australia and New Zealand. Winnipeg, Manitoba: University of Manitoba Press. 24-48.

CIA (Central Intelligence Agency). 2017. The World factbook: Greenland.

https://www.cia.gov/library/publications/the-world-factbook/ geos/gl.html

City of Yellowknife. 2015. Yellowknife point in time (PIT) count report 2015. Yellowknife: City of Yellowknife.

Dahl, J. 2010. Identity, urbanization and political demography in Greenland. Acta Borealia 27(2):125-140. https://doi.org/10.1080/08003831.2010.527528

Departementet for Familie og Sundhed. 2008. Hjemløs i Grønland: Et skøn over samtlige kommuners hjemløse [Homelessness in Greenland: An estimate of homelessness by municipality]. Nuuk, Greenland: Departementet for Familie og Sundhed.

Dollerup-Scheibel, M. 2016. Nej til at indkvartere hjemløse i containere [No to accommodating the homeless in shipping containers]. Nuuk, Greenland: Sermitsiaq.

Dybbroe, S., Dahl, J., and Müller-Wille, L. 2010. Dynamics of Arctic urbanization. Acta Borealia 27(2):120-124.

https://doi.org/10.1080/08003831.2010.527526

Dzik, A.J. 2016. Settlement closure or persistence: A comparison of Kangeq and Kapisillit, Greenland. Journal of Settlements and Spatial Planning 7(2):99-112. 
Falvo, N. 2011a. Homelessness in Yellowknife: An emerging social challenge. Toronto, Ontario: The Canadian Homelessness Research Network Press.

- 2011b. Who pays, when, and how? Government-assisted housing in the Northwest Territories and the role of the federal government. In: Stoney, C., and Doern, B., eds. How Ottawa spends, 2011-2012. Montreal, Quebec: McGill-Queen's University Press. 243-261.

Fievé, J., and Hansen, P. 2016. Flere kvinder søger hjælp [More women are seeking help]. Nuuk, Greenland: KNR.

Fossland, T.M. 2012. Highly skilled migration in the urban Arctic: A Norwegian case study on skilled migrant labour market integration. Polar Record 48(3):254-258.

https://doi.org/10.1017/S0032247412000071

Government of Nunavut. 2010. Nunavut housing needs survey. Iqaluit, Nunavut: Government of Nunavut. http://www.stats.gov.nu.ca/en/Housing.aspx

Grønlands Politi. 2016. Aarsstatistik 2016 [Annual statistics 2016]. Nuuk, Greenland: Grønlands Politi.

Grydehøj, A. 2014. Constructing a centre on the periphery: Urbanization and urban design in the island city of Nuuk, Greenland. Island Studies Journal 9(2):205-222.

Hamilton, L.C., and Seyfrit, C.L. 1994a. Female flight? Gender balance and outmigration by Native Alaskan villagers. Arctic Medical Research 53(Suppl. 2):189-193.

- 1994b. Coming out of the country: Community size and gender balance among Alaska Natives. Arctic Anthropology 31(1):16-25.

Hansen, K.E., and Andersen, H.T. 2013. Hjemløshed i Grønland [Homelessness in Greenland]. Aalborg, Denmark: Statens Byggeforskningsinstitut, University of Aalborg.

Hansen, K.G., Bitsch, S., and Zalkind, L. 2013. Urbanization and the role of housing in the present development process in the Arctic. Nordregion Report 2013:3. Stockholm, Sweden: Nordregio.

Hedwig, T.H., and Barker, R. 2016. Exploring the boundaries of public space in the urban North. Medicine, Anthropology, Theory 3(1):86-98.

Hendriksen, K. 2013. Grønlands bygder: Økonomi og udviklingsdynamik [Greenland's settlements: Economic and development dynamics]. Aalborg, Denmark: Aalborg Universitet and Danmarks Tekniske Universitet.

Howe, E.L. 2009. Patterns of migration in Arctic Alaska. Polar Geography 32(1-2):69-89.

https://doi.org/10.1080/10889370903000422

HUD (U.S. Department of Housing and Urban Development). 2011. Alaska Native housing needs: Outreach session proceedings report. Washington, D.C.: HUD.

https://portal.hud.gov/hudportal/documents/huddoc?id=finalak-proceedings.pdf

- 2017. Housing choice vouchers fact sheet. Washington, D.C.: HUD.

https://www.hud.gov/topics/housing_choice_voucher_ program_section_8

Inuvik Interagency Committee. 2003. Inuvik: Homelessness report. Inuvik, Northwest Territories: Inuvik Interagency Committee.
2006. Homelessness: State of response in Inuvik, NWT. Inuvik, Northwest Territories: Inuvik Interagency Committee. Jensen, F.T. 1982. Det spændende projekt »Allu«: glimt af KFUK's sociale arbejde i Grønland ved formanden Fanny Truels Jensen [The exciting project "Allu": A glimpse of KFUK's social work in Greenland with chairman Fanny Truels Jensen]. Nuuk, Greenland: Atuagagdliutit.

Kleist, P. 1997. Hjemløs beder om hjælp [The homeless ask for help]. Nuuk, Greenland: Atuagagdliutit.

Klodawsky, F. 2006. Landscapes on the margins: Gender and homelessness in Canada. Gender, Place \& Culture 13(4):365-381.

https://doi.org/10.1080/09663690600808478

Lauster, N., and Tester, F. 2014. Homelessness and health in the crowded Canadian Arctic: Inuit experiences. In: GuirguisYounger, M., McNeil, R., and Hwang, S.W., eds. Homelessness and health in Canada. Ottawa, Ontario: University of Ottawa Press. 87-110.

Levac, D., Colquhoun, H., and O'Brien, K. 2010. Scoping studies: Advancing the methodology. Implemention Science 5: 69. https://doi.org/10.1186/1748-5908-5-69

Martin, S., and Meléndez, A.V. 2010. Youth in crisis: Characteristics of homeless youth served by Covenant House Alaska. Anchorage, Alaska: Institute of Social and Economic Research.

McClain-Owens, E.V. 2012. Exploring the lives of homeless women in Anchorage, Alaska: A generic qualitative study/ thematic analysis. PhD thesis, Capella University, Minneapolis, Minnesota.

Mechan, K. 2013. Enriching our understanding of homelessness: What we know in Whitehorse. Whitehorse: Yukon AntiPoverty Coalition.

Minich, K., Saudny, H., Lennie, C., Wood, M., WilliamsonBathory, L., Cao, Z., and Egeland, G.M. 2011. Inuit housing and homelessness: Results from the International Polar Year Inuit Health Survey 2007-2008. International Journal of Circumpolar Health 70(5):520-531.

https://doi.org/10.3402/ijch.v70i5.17858

Murphy, D. 2014. Fewer than 100 people officially "homeless" in Nunavut's major centres. Nunatsiaq News, June 2.

Nunavut Housing Corporation. 2012. Igluliuqatigiilauqta (Let's build a home together): GN long-term comprehensive housing strategy. Iqaluit: Government of Nunavut.

— 2013. The GN long-term comprehensive housing and homelessness strategy. Iqaluit: Government of Nunavut.

- 2016. GN's blueprint for action on housing. Iqaluit: Government of Nunavut.

http://blueprintforaction.ca/

NWT (Northwest Territories) Housing Corporation. 2008. Framework for action 2008-2011. Yellowknife: Government of the Northwest Territories.

- 2015. Annual Report 2014-2015. Yellowknife: Government of the Northwest Territories.

2016. Homelessness in Yellowknife: Community Partnership Forum April 26-27, 2016. Yellowknife: Government of the Northwest Territories. 
Nyseth, T., and Pedersen, P. 2014. Urban Sámi identities in Scandinavia: Hybridities, ambivalences and cultural innovation. Acta Borealia 31(2):131 - 151 . https://doi.org/10.1080/08003831.2014.967976

Pedersen, C.P., and Bjerregaard, P. 2012. Det svære ungdomsliv unges trivsel i Grønland 2011: En undersøgelse om de ældste folkeskoleelever [The difficult life of youth - the wellbeing of youth in Greenland 2011: A survey of the oldest high school students]. Copenhagen: Statens Institut for Folkesundhed.

Poole, N., and Bopp, J. 2015. Using a community of practice model to create change for northern homeless women. The First Peoples Child \& Family Review 10(2):122 - 130.

Poppel, M. 2010. Kvinder og velfærd i Grønland [Women and welfare in Greenland]. In: Rafnsdóttir, G.L., ed. Kvinder og velfærd i Vestnorden. Copenhagen, Denmark: Nordisk Ministerraad. 39-68.

- 2016. Citizenship of Indigenous Greenlanders in a European nation state: The inclusionary practices of Iverneq. In: Moose-Mitha, M., and Dominelli, L., eds. Reconfiguring citizenship: Social exclusion and diversity within inclusive citizenship practices. London, United Kingdom: Routledge. $127-136$.

Raadet for Socialt Udsatte. 2016. Udsatte grønlandske kvinder i København - En undersøgelse af kvindernes livssituation, problemer, ressourcer og behov [Marginalized Greenlandic women in Copenhagen - a survey of women's life situations, problems, resources and needs]. Copenhagen: Raadet for Socialt Udsatte.

Rasmussen, R.O. 2010. Mobilitet i Grønland: Sammenfatning af hovedpunkter fra analysen af mobiliteten i Grønland [Mobility in Greenland: Summary of main points from an analysis of mobility in Greenland]. Nuuk, Greenland: Mobilitetsstyregruppen.

- 2011. Why the other half leave: Gender aspects of northern sparsely populated areas. In: Carson, D., Rasmussen, R.O., Ensign, P., Huskey, L., and Taylor, A., eds. Demography at the edge: Remote human populations in developed nations. Farnham: Ashgate. 237-254.

Roerdam, B. 2016. Mange hjemløse i Grønland [Many homeless in Greenland]. Hus Forbi 20(1):5-6.

Rosay, A. 2005. Homeless youths in Homer: A picture of their needs. Alaska Justice Forum 22(2):11 - 12.

Rosing Olsen, T. 2005. I skyggen af kajakkerne: Grønlands politiske historie 1939-79 [In the shadow of kayaks: Greenland's political history 1939-79]. Nuuk, Greenland: Atuagkat.

Schmidt, R., Hrenchuk, C., Bopp, J., and Poole, N. 2015. Trajectories of women's homelessness in Canada's 3 northern territories. International Journal of Circumpolar Health 74(1): 29778. https://doi.org/10.3402/ijch.v74.29778

Sejersen, F. 2010. Urbanization, landscape appropriation and climate change in Greenland. Acta Borealia 27(2):167-188. https://doi.org/10.1080/08003831.2010.527533
Seyfrit, C.L., Hamilton, L.C., Duncan, C.M., and Grimes, J. 1998. Ethnic identity and aspirations among rural Alaska youth. Sociological Perspectives 41(2):343-365. https://doi.org/10.2307/1389481

Shimer, S., Driscoll, D., Johnston, J., Hedwig, T.H., Barker, R., and Chapman, C. 2014. Housing First an effective solution to homelessness in Alaska. 142nd American Public Health Association Annual Meeting and Exposition: Proceedings of a conference held 11-14 November 2014, New Orleans, Louisiana. Article no. 307536.

Skatte- og Velfærdskommissionens betænkning. 2011. Vores velstand og velfærd -kræver handling nu [Our prosperity and our wellbeing require action now]. Nuuk, Greenland: Grønlands Selvstyre.

Standing Senate Committee on Aboriginal Peoples. 2017. We can do better: Housing in Inuit Nunangat. Ottawa: 42nd Parliament of Canada.

Tester, F.J. 2006. Iglutaq (in my room): The implications of homelessness for Inuit. A case study of housing and homelessness in Kinngait, Nunavut Territory. Kinngait, Nunavut: The Harvest Society.

—. 2009. Iglutaasaavut (our new homes): Neither "new" nor "ours": Housing challenges of the Nunavut Territorial Government. Journal of Canadian Studies 43(2):137-158. https://doi.org/10.3138/jcs.43.2.137

Tester, F.J., and Kulchyski, P.K. 1994. Tammarniit (mistakes): Inuit relocation in the Eastern Arctic, 1939-63. Vancouver, British Columbia: UBC Press.

Tierney, G. 2005. Street moves: Management of spoiled identity in the subculture of Alaska Native street people. International Journal of the Humanities 3(5):51 - 56.

Travis, R. 1991. Homelessness, alcoholism, and ethnic discrimination among Alaska Natives. Arctic 44(3):247-253. https://doi.org/10.14430/arctic1545

Tròndheim, G. 2010. Kinship in Greenland - emotions of relatedness. Acta Borealia 27(2):208-220. https://doi.org/10.1080/08003831.2010.527536

Udvalget For Samfundsforskning i Grønland. 1960. Rapport til Grønlands Landsraad om alkohol situationen i Grønland [Report to Greenland National Congress on the alcohol situation in Greenland]. Copenhagen: Udvalget for Samfundsforskning i Grønland.

U.S. Census Bureau. 2012. 2010 census of population and housing. Population and housing unit counts, CPH-2-3, Alaska. Washington, D.C.: U.S. Government Printing Office. https://www.census.gov/prod/cen2010/cph-2-3.pdf

Vammen, T. 2003. Fanny Truels Jensen (1915-1998): Dansk kvindebiografisk leksikon [Fanny Truels Jensen (1915-1998): Danish women's biographical lexicon]. Copenhagen, Denmark: KVINFO. https://www.kvinfo.dk/side/597/bio/1260/origin/170/

Wagner Sørensen, B. 1994. Jagten paa den indre grønlænder: Køn, kultur og identitet [The pursuit of the inner Greenlanders: Gender, culture and identity]. Kvinder, Køn and Forskning 3(2):53-68. 
1999. Alkohol i Grønland: Problemorienteret forskning i lokal drikkekultur [Alcohol in Greenland: Problem-oriented research in local drinking culture]. Antropologi 39:137-154.

Webster, A. 2006. Homelessness in the territorial North: State and availability of the knowledge. Ottawa, Ontario: Housing and Homelessness Branch, Human Resources and Social Development Canada.

Westfall, R. 2010. Whitehorse housing adequacy study. Whitehorse: Yukon Health and Social Services, Yukon Government.

Wilson, M., and Lowe, M. 2007. The extent of homelessness in the Kenai Peninsula Borough. Anchorage, Alaska: Institute of Social and Economic Research.

Yellowknife Homelessness Coalition. 2007. Planning for Phase III of the community plan to address homelessness in Yellowknife. Yellowknife: Yellowknife Homelessness Coalition.

- 2009. Yellowknife homelessness report card 2008. Yellowknife: Yellowknife Homelessness Coalition. http://ywcacanada.ca/data/research_docs/00000153.pdf

Young, M.G. 2013. Rural migration and homelessness in the North. Victoria, British Columbia: Royal Roads University.
- 2016. Help wanted: A call for the non-profit sector to increase services for hard-to-house persons with concurrent disorders in the western Canadian Arctic. The Extractive Industries and Society 3(1):41-49. https://doi.org/10.1016/j.exis.2015.11.008

Young, M.G., and Manion, K. 2017. Harm reduction through housing first: An assessment of the Emergency Warming Centre in Inuvik, Canada. Harm Reduction Journal 14(8): online.

https://harmreductionjournal.biomedcentral.com/ articles/10.1186/s12954-016-0128-8

Young, M.G., and Moses, J. 2013. Neoliberalism and homelessness in the western Canadian Arctic. Canadian Journal of Nonprofit and Social Economy Research 4(2):7-22.

https://doi.org/10.22230/cjnser.2013v4n2a147

Yukon Anti-Poverty Coalition. 2011. A home for everyone: A housing action plan for Whitehorse. Whitehorse: Yukon AntiPoverty Coalition.

Yukon Housing Corporation. 2009. Social housing evaluation report. Whitehorse: Yukon Government.

. 2014. Social housing evaluation report. Whitehorse: Yukon Government. 